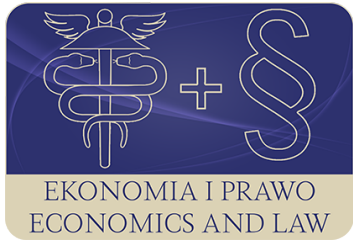

EKONOMIA I PRAWO. ECONOMICS AND LAW

Volume 16, Issue 4, December 2017

p-ISSN 1898-2255, e-ISSN 2392-1625

www.economicsandlaw.pl

\title{
Designing a fiscal union for the euro area
}

\author{
MAGDALENA KĄKOL \\ Maria Curie-Skłodowska University, Faculty of Economics, Department of World Economy and \\ European Integration, Plac Marii Curie-Skłodowskiej 5, 20-031 Lublin, Poland \\ $\square$ mkakol@hektor.umcs.lublin.pl
}

\begin{abstract}
Motivation: Fiscal integration constitutes an important adjustment mechanism to cope with asymmetric shocks within a monetary union which does not fulfil many criteria of an optimal currency area. As is currently the case in the euro area, national governments implement discretionary fiscal policy to try to cope with the adverse economic shocks themselves and to try to stabilise income which leads to high budget deficits and public indebtedness in many euro area countries. While conducting fiscal policy at supranational level and fiscal transfers within EMU would allow for sufficient cross-country risk sharing and contribute to macroeconomic stability of the whole euro area.

Aim: The aim of the paper is to give economic rationale and explain the significance of fiscal union for the effective functioning of a common currency area, and especially its macroeconomic stability as well as to present various forms of fiscal integration and to assess the possibility of their introduction within the euro area taking into account the current degree of economic integration, principles of conducting macroeconomic policy and its outcomes, the actual situation in the field of public finances and political circumstances in EMU and its member countries.

Results: The greatest potential for macroeconomic stability - both in terms of asymmetric shocks, as well as these affecting the entire euro area - ensures the establishment of a large federal Eurozone budget. However, in a situation of a lack of political will to move forward into a political union, the approach to ensure fiscal stabilisation should include: creating even a small euro area-wide budget and the common Ministry of Finance, introducing a European unemployment (re-)insurance scheme with further harmonization of labour markets, equipping the banking union with a fiscal backstop as well as making national fiscal policies more stabilising and avoiding to impose self-defeating fiscal adjustments on crisis countries.
\end{abstract}


Keywords: EMU; fiscal union; euro area budget

JEL: E61; E62; E63; F36; F42; F45

\section{Introduction}

The euro area was provided with the competence to conduct the single monetary policy while fiscal policy was left to the member countries. The lack of sufficient real convergence of their economies has been neglected and, in the absence of effective adjustment instruments, a few Eurozone members were forced to use fiscal policy to counter the often pro-cyclical impact of monetary policy, even despite the Maastricht criteria and the Stability and Growth Pact rules. The financial and economic crisis (2008/2009) revealed critical design failures in the EMU architecture. Its main outcome is the huge public indebtedness of many euro area countries. The synchronisation of economic cycles of the periphery and the core countries (and also within the group of peripheral countries) fell markedly after the crisis (Belke et al., 2016) and as a result they are exposed to a greater extent to asymmetric shocks. A range of reforms that were supposed to strengthen the resilience of EMU: the overhaul of the fiscal governance framework (the six-pack and two-pack legislation, the Fiscal Compact), the macroeconomic imbalance procedure, the creation of crisis resolution mechanisms (the European Stability Mechanism and the Outright Monetary Transactions), the establishment of the first pillars of a banking union - proved to be insufficient to ensure the macroeconomic stability of the euro area and its member countries. In these circumstances, a debate on a new common fiscal shock absorbing capacity was started that would allow for sufficient cross-country risk sharing and contribute to macroeconomic stability of the whole euro area. The creation of a fiscal solidarity instrument was advocated by representatives of many EU institutions: in the 'Four Presidents' Report (Van Rompuy et al., 2012); the European Commission's Blueprint for a deep and genuine EMU (European Commission, 2012), the 'Five Presidents' Report (Juncker et al., 2015) and at the beginning of 2017 the European Parliament 'gave green light' for introducing the common euro area budget.

The aim of the paper is to give economic rationale and explain the significance of fiscal union for the effective functioning of a common currency area, and especially its macroeconomic stability as well as to present various forms of fiscal integration and to assess the possibility of their introduction within the euro area taking into account the current degree of economic integration, principles of conducting macroeconomic policy and its outcomes, the actual situation in the field of public finances and political circumstances in EMU and its member countries. 


\section{Research methodology}

When discussing economic rationale and potential forms of fiscal integration within Eurozone, the theory of fiscal federalism should be used as guidance, although the Optimal Currency Area (OCA) theory as well as different approaches of main economic schools to the role of fiscal policy in an economy (including its stabilisation function) could also be helpful. The paper has been focused on selecting and highlighting the most important arguments in the ongoing economic debate in favour of introducing a fiscal union in the euro area from a theoretical perspective and based on empirical data.

The following research methods were used: a critical assessment of the scientific acquis related to fiscal integration incorporated in various theories of economics, a comparative analysis of literature, EU documents and principles concerning the functioning of EMU as well as an analysis of empirical studies and statistical data on public finances and fiscal policies of the euro area member countries: Eurostat (2017), Ameco (2017), and IMF (2017a, 2017b) databases.

\section{Theoretical approach to fiscal integration within the euro} area

There is no single and clear-cut definition of fiscal federalism (or fiscal union) in economic literature. As stated by Bordo et al. (2013, p. 451), 'the concept of a fiscal union entails fiscal federalism among its members, which could be either sub-national (sub-central or regional) political units or nation states'. Dabrowski (2015, p. 7) underlines that such federalism (and fiscal union) involves a partial transfer of fiscal resources and competences in the field of fiscal policy including fiscal management from the national to supranational level. Interpretations of terms: 'fiscal federalism', 'fiscal union' and 'fiscal integration' range from a set of common fiscal rules to the creation of a fully federal government with tax and spending powers (Thirion, 2017, p. 3).

There are also more complex definitions of fiscal federalism and fiscal integration, the authors of which stress that this is a tedious process composed of many elements. For Bordo et al. (2013, p. 451), who base their definition on the findings of Sorens (2008), only adding the last condition, perfect fiscal federalism consists of the five elements: (1) autonomy of sub-central political entities to decide taxes and expenditures; (2) hard budget constraints for local governments including a no-bailout rule; (3) existence of a common market based on free trade and mobility within the fiscal union which ensures competition among sub-central governments; (4) institutionalisation of fiscal federalism system in a set of rules, and (5) common currency shared by the sub-central and the central fiscal authorities as they are not only participants of the common market but also of the same monetary union. 
According to Oates (1999, pp. 1121-1122), the theory of fiscal federalism should help us assign different functions and instruments of fiscal policy to an appropriate government level in order to increase its effectiveness and economic welfare. The aim of the central government and a federal budget is threefold (Bénassy-Quéré et al., 2016, p. 4): (1) to finance those public goods that are common to all regions or states constituting a federation (e.g. defence, diplomacy, R\&D, infrastructure), (2) to carry out transfers between regions to compensate geographical or historical disadvantages, and to maintain economic and social cohesion within a federal state, (3) to ensure macroeconomic stabilisation by smoothing out business fluctuations in line with the GDP trend at a national level and across the regions. The latter task cannot usually be realised by local budgets as they are often constrained by tight balanced-budget rules (including a no-bailout rule by the federal government to reduce moral hazard, i.e. the natural tendency of local authorities to increase debt if there are no fiscal limitations). Therefore the main purpose of lower levels of government should be provision of public goods whose production and consumption is limited to their own jurisdictions (Oates, 1999, p. 1122).

Within a current EU governance framework the general budget is very small (around $1 \%$ of EU GNI and 2\% of public expenditures of member states) and entirely devoted to the first two objectives of fiscal policy. It cannot perform stabilisation functions not only because of its modest size but also as a result of the absolute principle of budget balance. Meanwhile, of the three main functions of fiscal policy (provision of public goods, redistribution and stabilisation) only the last fully justifies conducting this policy at the EMU level (see Bénassy-Quéré et. al. (2016, p. 2)). At the time being, in the euro area (i.e. a monetary union with the single monetary policy) the ECB plays a stabilising role against shocks affecting the Eurozone as a whole (e.g. it cuts interest rates in downturns and raises them in upturns), but in the case of shocks affecting individual member countries there is ample room to address them through national fiscal policies. As unsustainable fiscal policy in one or a few member states could destabilise the entire monetary union due to direct and indirect demand effects with an impact on euro area-wide inflation it should be subject to fiscal discipline and sufficient coordination at the central level. However, even if these requirements are formally met - unless the common currency area is to a large extent optimal (including high business cycle synchronisation) - there is a danger of pro-cyclicality of fiscal policy performed at national level (both for certain member countries as well as for the whole euro area). Empirical data on the outcomes of domestic fiscal policies in the Eurozone so far seem to confirm this (see e.g. Huart (2013, pp. 73-88); Nerlich \& Reuter (2015)).

That is why most scholars agree that in federations the macroeconomic stabilisation should be implemented at the central level. The stabilisation of economic activity via fiscal policy relies on supporting the economy through higher expenditures or lower taxes in a downturn, and reducing the budget deficit in an upturn. This can be realised by two main channels: (1) automatic stabilis- 
ers that smooth economic activity through the automatic response of taxes and transfer systems to the business cycle; (2) discretionary fiscal policy measures, i.e. changes in government expenditures and less often taxes as a result of fiscal authorities' decisions. However, most evidence points to a significant countercyclical role of automatic stabilisers rather than of discretionary fiscal measures (Bańkowski \& Ferdinandusse, 2017, p. 16). In the euro area automatic stabilisers are larger than in the US (they smooth $38.5 \%$ of a proportional income shock in the EU on average while in the US only $34 \%$ ), but their effects vary greatly between member countries (from around 30\% in PIGS countries to over 50\% in Belgium) (Dolls et al., 2012). Though fiscal stabilisers operate well in case of small shocks, the lack of 'regional' governments' control over the currency in which their debt is issued may cause problems during a severe crisis, especially for countries that accumulated large imbalances and external debt. The most vulnerable member states may find it difficult to finance themselves in financial markets and increasing sovereign debt yields can force them to cut automatic stabilisers which leads to further recessionary pressures (De Grauwe, 2016, p. 152; Thirion, 2017, p. 12). Therefore, in some situations the discretionary fiscal policy is justified (e.g. during large economic shocks leading to crises) or even considered as being the most effective way to stabilise the economy, e.g. when monetary policy is constrained by the zero lower bound. In such circumstances government spending multiplier is particularly high (Eggertsson, 2011; European Commission, 2016, pp. 137, 153) and temporary expenditure increases, as well as an appropriate revenue-neutral combination of changes in taxes, could deliver stimulus to the economy and replicate the effects of negative nominal interest rates (Correia, et. al., 2013). The fact that governments can become credit-constrained and may be forced to cut automatic stabilisers or discretionary spending during severe economic shocks is the rationale for a supranational fiscal-transfer instrument (at least against the largest shocks) in the Eurozone (Thirion, 2017, pp. 12-13).

According to the theory of optimum currency areas (OCAs) a system of federal fiscal transfers across a currency union's regions reduces the costs of monetary unification resulting from the loss of national monetary policy and nominal exchange-rate adjustment mechanism when a country is affected by an adverse country-specific shock (Kenen, 1969). Other adjustment mechanisms that allow for alleviating the consequences of asymmetric shocks in a monetary union are market-based and include the high mobility of labour and capital, the flexibility of prices and wages as well as financial market integration (Mundell, 1961 and 1973; McKinnon, 1963). Mundell (1973), highlights that private risk-sharing through the sufficiently integrated capital and credit markets could provide adequate insurance against shocks when economic cycles are not synchronised, which makes a fiscal union unnecessary. As comfirmed by Eichengreen (1991, p. 17) interregional fiscal transfers financed through federal taxes are justifiable 'only if insurance cannot be provided by the market'. 
In federations macroeconomic stabilisation via the federal budget is achieved both at sub-national level (through temporary net transfers) as well as at the country level (through federal borrowing) (Bénassy-Quéré et al., 2016, p. 5 ). One of the most prominent advantages of a centralised fiscal system is that it allows for economies of scale to pursue stabilisation objectives because the central government can usually borrow from the market at lower costs (Bordo et. al., 2013, p. 455; Thirion, 2017, p. 11). However, besides fiscal risk-sharing, an important role in shock absorption is often played by market adjustment mechanisms including well integrated and developed financial markets. While private capital markets ensure diversification of financial portfolios and hence allow households or governments to diversify their income streams, cross-border credit markets facilitate saving in good times and borrowing in times of crisis not only to countries but also to public and private agents at sub-national level (Allard et. al., 2013, p. 14).

Recent studies (Allard \& Bluedorn, 2016; Bluedorn et al., 2013) show that in 3 large federal states - Canada, Germany, and the US - around $80 \%$ of income shocks to sub-national territorial units are smoothed mainly via private credit and capital markets (smoothing about $50-70 \%$ of shocks) and to a lesser extent via public transfers from the center to sub-national components (between $10-30 \%)$. By contrast, income shocks to Eurozone countries are only about $40 \%$ smoothed with fiscal risk-sharing (obtained through the EU budget) found to be nearly zero. The most striking difference between the US and EMU is the very low degree of risk-sharing via capital markets (i.e. international factor income) in EMU compared to the US (between 0-10\% in the Eurozone vs. almost $40 \%$ in the US) (Kalemli-Ozcan et al., 2014). Alleviating of negative shocks in the euro area occurs mainly through the credit channel: cross-border saving and borrowing. However, this channel is particularly fragile - tends to amplify shocks rather than smooth them (Thirion, 2017, p. 13). It breaks down in periods of financial crises, when risk sharing is most needed, as international credit markets become unwilling to grant loans, and this is especially the case in the euro area periphery (Furceri \& Zdzienicka, 2013; Kalemli-Ozcan et. al., 2014; Alcidi \& Thirion, 2016). In this context the idea to create the fully-fledged European banking union (with a common system of deposit reinsurance - i.e. some form of fiscal union) as well as the European capital markets union should be widely supported. Unfortunately, the current European Commission proposals concerning the latter institution are far too timid so as we could see much higher level of market risk-sharing in the Eurozone in the nearest future. Necessary integration of capital markets will require major steps in the areas of harmonization of accounting, insolvency, transparency and taxation (Véron \& Wolff, 2015). Though for some scholars (e.g. Gros \& Belke (2015)) risk-sharing through a well functioning banking union and a capital markets union may be sufficient to absorb losses from most financial shocks, for others (e.g. Farhi \& Werning (2017)) even complete financial integration 
must be supplemented by at least a minimum degree of fiscal insurance as it can be perceived by the market as a catalyst for private risk-sharing.

Thirion (2017, p. 11), emphasises that a perfectly designed fiscal capacity (a system of fiscal risk-sharing) for the euro area should allow to achieve three kinds of stabilisation: (1) of asymmetric shocks within EMU; (2) of the aggregate EMU business cycle (inter-temporal EMU-wide stabilisation), and (3) of domestic business cycles. However, gaining all three at the same time is an extremely difficult task. For instance, stabilising asymmetric shocks and a country's output gap can be reconciled only if the EMU output gap is constantly zero (country-specific shocks are randomly distributed around a constant Eurozone-wide growth tend). If it is not the case full fiscal risk-sharing could generate pro-cyclical fiscal policies at the country level as countries undergoing a downturn but doing relatively better than their neighbours during an euro area-wide recession would be forced to increase their net contribution. From this perspective, aiming at perfect fiscal risk-sharing might not be the best solution as regards national macroeconomic stability.

The rules of conducting fiscal policy in the euro area have been greatly influenced by the theory of economics and its evolution. While Keynesianism recognizes budget deficit as a necessary tool for stabilising economic growth, the new classical macroeconomics accepts a cyclical deficit (triggered by activity of automatic stabilisers) as a matter of necessity, but strongly opposes structural deficits and discretionary policy. In recent years, however, different approaches of many schools of economic thought to the stabilisation role of fiscal policy in an economy have been reconciled to some extent and the concept of fiscal sustainability has been gaining in popularity. It emphasises that ensuring safety of state finances is of no less importance than the needs of economic stabilisation (aiming at economic equilibrium and GDP growth). A sustainable fiscal policy can be defined as a policy leading to the ratio of debt to GDP eventually converging back to its initial level (Blanchard et. al, 1990, p. 11). Alesina (1994), stresses that maintaining fiscal sustainability requires relying on automatic stabilisers - a cyclical deficit is permissible because it gets reset during a business cycle whereas a structural deficit should be reduced to zero at the level of potential product (or be at a very low level on the assumption that public indebtedness is small). Permanent growth in the structural deficit means a continuous increase in sovereign debt, and a rise in its operating costs is becoming pro-recessionary. This reasoning was included in the rules of the Stability and Growth Pact according to which the assessment of fiscal policy in the euro area should be based on the size of structural balance. The euro area countries are supposed to pursue a rather passive fiscal policy (based on automatic stabilisers) within a business cycle and the structural deficit should not exceed $0.5-1.0 \%$ of GDP. 


\section{Empirical evidence on the outcomes of fiscal policies in the Eurozone concerning macroeconomic and fiscal stabilisation}

The existing fiscal policy framework does not ensure either macroeconomic or fiscal stability for many Eurozone countries, especially in hard economic times.

Fiscal stabilisation outcomes of national policies in the Eurozone were gathered in table 1. In 1999-2016 as many as 10 out of 19 euro area countries maintained an average general government deficit of over 3\% of GDP, with Greece, Portugal and France accounting for the highest number of breaches of the budget criterion. During that period Luxembourg, Estonia and Finland were most concerned about budgetary discipline among the Eurozone countries. While in the first years of the euro area functioning member countries managed to slightly reduce public debt levels (from $70.6 \%$ to $64.9 \%$ of GDP in 1999-2007 for EA-19 on average), the 2008/2009 financial and economic crisis and the use of fiscal policy to counteract its negative outcomes have led to a large increase in sovereign indebtedness in relation to GDP, especially in Greece and Portugal. In 2016 compared to 1999 public debt levels in relation to GDP were higher in 17 euro area countries and lower than their initial level only in two of them (Belgium and Malta). However, four large countries (Italy, Germany, France and Spain) have the greatest influence on fiscal stabilisation of the entire EMU with the combined share of almost $80 \%$ of total EA public debt in 2016. In three of these countries (excluding Germany) the level of sovereign indebtedness exceeded or was approaching 100\% of GDP in 2016. The dangerous phenomenon is not only the high level of public debt, but also its growing variation between member countries measured by standard deviation, even despite declining diversity in terms of budget deficits in 1999-2016. This also contributes to large differences in government bond yield spreads between the Eurozone countries (table 1).

Unfortunately, empirical research also fails to confirm the positive impact of fiscal policy in the euro area on the macroeconomic stability of the Eurozone as a whole as well as stability of certain member countries, i.e. its counter-cyclical impact on the economy.

Alcidi \& Thirion (2016, pp. 4-5) examined pro-cyclicality of fiscal policy at the euro area level and across member countries in 1995-2015. On the basis of behaviour of the discretionary component of the national fiscal policy stances over the cycle they found a pro-cyclical bias, with only 20 to $45 \%$ of episodes of counter-cyclicality, in the three sub-periods (pre-EMU, up to the crisis and the crisis) under consideration. As regards the entire euro area they considered the overall fiscal impulse (the structural and the discretionary component of the fiscal balance) and noticed that, on aggregate, fiscal policy was generally less pro-cyclical during the pre-crisis years than the analysis of individual coun- 
tries suggested. Their explanation for this was that larger countries (for instance Germany) were more counter-cyclical.

Bénassy-Quéré et al. (2016, pp. 6-7), emphasise that since 2008 fiscal policy in the Eurozone has not played its macroeconomic stabilisation role, except 2009 and 2011 when it was counter-cyclical. In 2008, 2012 and 2013 this policy was pro-cyclical (accentuated rather than attenuated the cycle), and in the other years - roughly neutral. Pro-cyclicality was mainly the result of the influence of the discretionary part of fiscal policy while automatic stabilisers generally worked well.

Data in chart 1 confirm the results of the cited empirical studies. The pro-cyclical discretionary component of fiscal policy (reflected by positive output gap and negative changes in the structural primary balance and vice versa) was strongly visible in 2000-2001 and 2012-2013. However, this trend was offset by the cyclical component (automatic stabilisers).

\section{Potential forms and elements of fiscal union in the euro area}

An important condition for a well functioning monetary union is the existence of a sufficiently large element of solidarity or risk-sharing. All federations (which also represent currency zones) have significant common budgets that alleviate the outcomes of negative shocks hitting their certain states or regions. Data in table 2 illustrate the significance of general government expenditure at central and lower levels in EA-19 countries and in some federal states. A very differentiated situation of the Eurozone countries in terms of the size and structure of public expenditure would undoubtedly hinder the complete unification of fiscal policy in the euro area.

Although federal states spend 11-35\% of their GDP through federal budgets (table 2) they finance many common goods, and macroeconomic stabilisation is only one of their aims. Assuming that the main purpose of euro area fiscal capacity (or its unique mandate) would be producing significant stabilisation, even a small common budget or a rainy day fund could provide enough business cycle smoothing, especially if it is focused on large shocks. According to Furceri \& Zdzienicka (2013), member countries' annual contributions of the order of $1.5 \%$ to $2.5 \%$ of GNP would have been sufficient to provide a level of risk-sharing comparable to that found in Germany ( $80 \%$ versus $40 \%$ for the Eurozone currently). Similar estimates were made by Wolff (2012) who propose a fiscal capacity of up to $2 \%$ of euro area GDP.

The crucial problem to solve during designing an effective fiscal risk-sharing device for the euro area is not only its size but also (Thirion, 2017, p. 17): deciding whether to equip it with the competence to borrow in financial markets when countries are simultaneously faced with a shock; choosing the appropriate measure of the position in the business cycle on which transfers and contributions are made (output gap or unemployment rate) and the way of redistributing 
funds to maximise the stabilisation effect; as well as avoiding moral hazard and permanent transfers.

We can distinguish two approaches to the creation of a euro area fiscal insurance mechanism against economic shocks. The macroeconomic approach assumes providing insurance either against country-specific shocks, against common euro area-wide shocks or both, on the basis of ex ante or ex post triggers based on macroeconomic performance indicators capturing the (relative) position of a country in the business cycle. Transfers are usually based on output gaps or unemployment rates and they are disbursed directly to governments experiencing the shock. It is left open whether a centralised fiscal risk-sharing should take the form of a genuine euro area budget with common revenue and expenditure, of a joint rainy day fund, or of unemployment insurance. The microeconomic approach envisages establishing a genuine common unemployment insurance scheme with unemployment benefits provided directly from the central level to individuals in countries hit by economic shocks. Such mechanisms already exist in federal states, e.g. in the United States (Iara, 2016, p. 305; Bénassy-Quéré et al., 2016, p. 14; Thirion, 2017, p. 17).

Among dozens of proposals of a common fiscal capacity some seem to be particularly interesting. The Tommaso Padoa-Schioppa Group (2012), proposes a rainy day fund with ex ante funding (annual contributions of the order of 1.5-2.5\% GDP) providing automatic macroeconomic fiscal insurance against country-specific shocks based on the national output gaps relative to the Eurozone output gaps. According to the authors, such a mechanism could limit the pro-cyclicality of the single monetary policy and accelerate synchronisation of economic cycles within EMU. However, if the euro-area ouput gap would be much lower than zero, countries hit by recession would be forced to pay those that were more severely affected. To avoid this problem some scientists suggest using country's own cyclical position, without its relativisation to the euro area as a whole (see e.g. Furceri \& Zdzienicka, (2013), Pisani-Ferry et al. (2013), Caudal et. al. (2013) and Carnot et al. (2015) propose solutions allowing for alleviating not only asymmetric but also common euro area-wide shocks. PisaniFerry et al. (2013) propose an automatic transfer scheme based on deviations from potential outputs (among three other alternatives including a fully federal euro area budget amounting to $2 \%$ of euro area GDP). To avoid moral hazard transfers would be made to governments only if the output gap is larger than a certain threshold (i.e. $2 \%$ ) and would cover $25 \%$ of the shock's size. Similarly Carnot et al. (2015) consider a payment threshold of about 25\% of country-specific output gaps from the fund collecting annual contributions of $0.8 \%$ of GDP from the Eurozone countries while Furceri \& Zdzienicka (2013), suggest providing transfers proportional to the size of the shock. The French Ministry of Finance is a supporter of a euro area budget (with borrowing capacity) consisting of cyclical revenues (including corporate income tax) and countercyclical expenditure (e.g. unemployment benefits) aiming at mitigating consequences of symmetric and asymmetric shocks. Economic cycle smoothing should be 
gained both through automatic stabilisers and discretionary measures (Caudal et al., 2013). The final stabilisation effects of the euro area capacity will depend not only on the size but also the trigger and speed of providing funds as well as the way of their allocation by member countries (which have an alternative option to use part of them to consolidate debts instead of increasing countercyclical spending).

Due to the frequent errors in estimating output gaps many analysts support the use of unemployment rate as an indicator (taking into account that it is a lagged measure) of the position in business cycle and the trigger of granting funds from a common fiscal capacity. Therefore, an academic debate has been concentrating on a European unemployment (re-)insurance mechanism that could work as an important automatic stabiliser in smoothing income and consumption levels. It can be designed as a system of re-insurance of existing national unemployment insurance schemes at the central level with intergovernmental transfers linked to short-term unemployment rates (macroeconomic approach) or as a fully-fledged European unemployment benefits insurance scheme for the euro area citizens with common financing and provisions (microeconomic approach). In the first case transfers to governments can be either earmarked or non-earmarked for unemployment benefit expenditure (Bontout \& Lejeune, 2013). Unemployment re-insurance schemes are proposed among others by the group of German analysts (von Bogdany et. al., 2013), who suggest allocating transfers linked to high short-term unemployment rates to growth-enhancing investments; by Gros (2014), who advocates financing unemployment benefits but on the condition of granting funds only in the situation of 'catastrophic', i.e. the largest economic shocks, which reduces the risk of moral hazard; and by Bénassy-Quéré et al. (2016) who emphasises that any common unemployment (re-)insurance scheme would require at least minimal harmonization of labour markets. A genuine euro area-wide unemployment insurance scheme to individuals (which would partly or fully replace national unemployment systems) is proposed by Pisani-Ferry et al. (2013), Dullien (2013) and Dolls et al. (2016). To minimize moral hazard Dolls et al. (2016, p. 220), point to the necessity of co-financing unemployment benefits by national systems and of compulsory adopting of the proposed sovereign insolvency procedure (including debt restructuring).

Due to the high euro area sovereign indebtedness eurobonds and other instruments designed to overcome it occupy an important place among many proposals enhancing fiscal risk-sharing between the Eurozone members. In 2011 the European Commission presented three options of eurobonds (Geeroms et al., 2014, p. 345): (1) fully fledged eurobonds with maximal risk-sharing, i.e. joint and several liability (meaning that each member state is responsible for the repayment of the full value of eurobond issue); (2) pooling only a portion of borrowings with joint and several guarantees; (3) covering only parts of national indebtedness with several but not joint government guarantees (responsibility of member states only for their share in the pooled debt). As the first two op- 
tions involve mutual bailing out of sovereign debts by member countries (which is forbidden by the TFEU) they need a Treaty change. Geeroms et. al. (2011), suggest a system of eurobonds issued at the same rate but with the receipts lent to member states using differentiated interest rates (as the average interest rate would be too high for the northern core countries and too low for the weaker ones). To deal with the problem of moral hazard Delpla \& Weizsäcker (2010), propose mutualisation of the first $60 \%$ of sovereign indebtedness to GDP which would benefit from joint and several liability of the euro area members ("Blue Bonds') and the remaining amount of national debt ('Red Bonds') which would be issued at higher costs related to the solvency and the riskiness of the country. Other related proposals include the creation of: a European Debt Agency issuing joint and several debt (Geeroms et al., 2014; Tommaso Padoa-Schioppa Group, 2012) or issuing debt without joint guarantees (Brunnermeier et. al., 2011); a European Debt Redumption Fund refinancing the member states' public debt over $60 \%$ of GDP by eurobonds (Geeroms et al., 2014) as well as of a European Monetary Fund - partially prefinanced by countries that breach the Maastricht fiscal criteria (Gros \& Mayer, 2010).

The introduction of a Single Resolution Mechanism (the second pillar of the banking union) with a common resolution fund prefinanced by the banking industry (another example of a kind of budget for the euro area) is an important stabilising tool because major asymmetric shocks are caused by problems in the financial sector (Gros, 2014). It should also help to limit future bank bailout costs for governments. However, completing a banking union with a third pillar (European Deposit Insurance System) backed by a common fiscal backstop as well as a further denationalisation of banking policies (including less and diversified exposure to sovereign debt) are necessary in order to prevent the feedback loop between sovereign and banks (Demertzis \& Wolff, 2016).

Deepening of fiscal integration comprises also some proposals aiming at strengthening the scope of coordination, effectiveness and elasticity of national fiscal policies within the euro area: (1) by creating a supranational institution with a finance minister with veto power on member countries' budgets (Enderlein \& Haas, 2015); (2) by empowering the planned independent European Fiscal Board with identifying exceptional times during which coordination is needed on top of monetary policy; (3) by replacing the insufficient flexibility of the SPG with respect to the economic cycle by national adjustment accounts that would shift selective cyclical spending form 'bad' to 'good' times when calculating budget deficits which helps to limit self-defeating fiscal adjustments imposed on crises countries (Bénassy-Quéré et al., 2016).

\section{Conclusion}

The theory of fiscal federalism indicates that macroeconomic stabilisation in the common currency zone can be more effectively achieved via central budget than local ones. Similar conclusions can be drawn on the basis of the OCA theory 
which underlines an important role of fiscal transfers between monetary union's countries that do not form an optimal currency area and do not have a sufficiently large, deep and well-integrated capital market (i.e. private risk-sharing). The consensus developed by various economics schools in the course of their evolution supports the concept of fiscal sustainability which suggests that fiscal policy should be primarily based on automatic stabilisers with the structural budget balance (reflecting discretionary policy) at the very low level, especially in times of prosperity.

The euro area macroeconomic performance so far (the average annual structural budget deficit of $2.5 \%$ of potential GDP (IMF, 2017b), an increasing level of public indebtedness from $70.6 \%$ to $91.5 \%$ of GDP, and in particular the prevailing pro-cyclicality of fiscal policy in 1999-2016) confirms that the current fiscal framework (the Maastricht criteria, the SGP, the six-pack and two-pack legislations, the European Stability Mechanism and the Fiscal Compact) has failed and better solutions, based on some form of fiscal risk-sharing at the central level, should be sought.

Among various proposals of instruments, which may become components of a fiscal union in the euro area, the following are mentioned most often: a federal budget with own taxes and expenditure (possibly combined with borrowing capacity); a European unemployment (re-)insurance scheme with better harmonization of labour markets; other fiscal (shock absorbing) insurance mechanisms of transfers between countries (including rainy day funds); a larger EU budget and European taxes; harmonization of taxation; joint guarantee for government debt; supplementing the banking union with a common deposit insurance and/or a fiscal backstop; insolvency procedure for sovereigns; fiscal rules, policy coordination and supervision; a crisis resolution mechanism (extending the remit of the European Stability Mechanism); making national fiscal policies more stabilising by allowing incremental investment and unemployment expenditure to be shifted from bad to good times based on national adjustment accounts; the creation of an advisory European Fiscal Board, composed of independent experts, tasked with providing recommendation to the EC on the Eurozone fiscal stance; the creation of institutions with fiscal authority on a supranational level (the euro area finance minister). A fiscal union may, but does not have to, include all of them.

As emphasised by De Grauwe (2016, p. 155) there is no future for the euro without a minimum of solidarity and 'the Eurozone can only be sustained if it is embedded in a fiscal and political union'. Such a fiscal union should involve: (1) a (partial) consolidation of national government indebtedness, i.e. a common fiscal authority which can issue debt under the control of that authority, and (2) a (partial) centralisation of national government budgets into one central budget, i.e. a mechanism of automatic fiscal transfers.

At present full fiscal unification (centralisation of national budgets and conducting fiscal policy at the euro area level) and a political union seem impossible both for economic reasons (large differences between member countries 
in terms of GDP per capita, the size of public expenditures in relation to GDP and their structure, unemployment benefits and taxation systems, etc.) as well as political ones (the unwillingness of many states to completely renounce national sovereignty). There is also a great reluctance of some countries (e.g. Germany and the Netherlands) to mutualisation of national debt, and their attitude towards this issue is unlikely to change in the near future. However, recent events (long-term economic stagnation after the 2008/9 crisis, the Brexit decision in 2016 and the win of pro-European politicians in the Netherlands and France elections) have led to a political will in most of the Eurozone countries to launch a substantive discussion on a common fiscal capacity dedicated just for the euro area. It is difficult to clearly prejudge which form it will take - perhaps it will include several elements mentioned above (such as a small common budget, a European unemployment (re-)insurance scheme, a common deposit insurance and the Eurozone finance minister).

\section{References}

Alcidi, C., \& Thirion, G. (2016). Assessing the euro area's shock-absorption capacity. Risk sharing, consumption smoothing and fiscal policy. CEPS Special Report, 146.

Alesina, A. (1994). Political models of macroeconomic policy and fiscal reforms. In S. Haggard, \& S. Webb (Eds.), Voting for reform. Oxford: Oxford University Press.

Allard, C., \& Bluedorn, J.C. (2016). Towards a fiscal union for the eurozone. Retrieved 30.03.2017 from https://voxeu.org.

Allard, C., Brooks, P.K., Bluedorn, J.C., Bornhorst, F., Christopherson, K., Ohnsorge, F., Poghosyan T., \& an IMF staff team. (2013). Towards a Fiscal Union for the Euro Area. IMF Staff Discussion Note, 13/09.

Ameco. (2017). Ameco database. Retrieved 17.04.2017 from https://ec.europa.eu.

Bańkowski, K., \& Ferdinandusse, M. (2017). Euro area fiscal stance. ECB Occasional Paper Series, 182.

Belke, A., Domnick, C., \& Gros, D. (2016). Business cycle synchronization in the EMU: Core vs. periphery. CEPS Working Document, 427.

Bénassy-Quéré, A., Ragot, X., \& Wolff G.B. (2016). Which fiscal union for the euro area? Bruegel Policy Contribution, 05.

Blanchard, O., Chouraqui, J.C., Hagemann, R.P., \& Sartor, N. (1990). The sustainability of fiscal policy: New answers to an old question. OECD Economic Studies, 15.

Bluedorn, J., Furceri, D., Jaumotte, F., Ohnsorge, F., Poghosyan, T., \& Zdzienicka, A. (2013). Fiscal risk sharing: New evidence for the euro area. Technical Background Note to IMF Staff Discussion Note, 13/09.

Bontout, O., \& Lejeune, G. (2013). Paper on automatic stabilisers. Brussels: European Commission. 
Bordo, M.D., Jonung, L., \& Markiewicz, A. (2013). A fiscal union for the Euro: some lessons from history. CESifo Economic Studies, 59(3). doi:10.1093/ cesifo/ift001.

Brunnermeier, M.K., Garicano, L., Lane, P.R., Pagano, M., Reis, R., Santos, T., Thesmar, D., Van Nieuwerburgh, S., \& Vayanos, D. (2011). European safe bonds (ESBies). Retrieved 15.05.2017 from http://www.euro-nomics.com.

Carnot, N., Evans, P., Fatica, S., \& Mourre, G. (2015). Income insurance: a theoretical exercise with empirical application for the euro area. European Economy Economic Papers, 546.

Caudal, N., Georges, N., Grossmann-Wirth, V., Guillaume, J., Lellouch, T., \& Sode, A. (2013). A budget for the euro area. Trésor-Economics, 120.

Correia, I., Farhi, E., Nicolini, J., \& Teles, P. (2013), Unconventional fiscal policy at the zero bound. American Economic Review, 103(4). doi:10.1257/ aer.103.4.1172.

Dabrowski, M. (2015). Monetary union and fiscal and macroeconomic governance. European Economy. Discussion Paper, 013.

De Grauwe, P. (2016). The legacy of the Eurozone crisis and how to overcome it. Journal of Empirical Finance, 39. doi:10.1016/j.jempfin.2016.01.015.

Delpla, J., \& von Weizsäcker, J. (2010). The blue bond proposal. Bruegel Policy Brief, 03.

Demertzis, M., \& Wolff, G. (2016). What are the prerequisites for a euro-area fiscal capacity? Bruegel Policy Contribution, 14.

Dolls, M., Fuest, C., Heinemann, F., \& Peichl, A. (2016). Reconciling insurance with market discipline: a blueprint for a European fiscal union. CESifo Economic Studies, 62(2). doi:10.1093/cesifo/ifw004.

Dolls, M., Fuest, C., Neuman, D., \& Peichl, A. (2012). Automatic stabilizers and economic crises: US vs. Europe. Journal of Public Economics, 96(3-4). doi:10.1016/j.jpubeco.2011.11.001.

Dullien, S. (2013). A euro area wide unemployment insurance as an automatic stabilizer: Who benefits and who pays? Brussels: European Commission.

Eggertsson, G. (2011). What fiscal policy is effective at zero interest rates? In D. Acemoglu \& M. Woodford (Eds.), NBER Macroeconomics Annual 2010, 25. Chicago: University of Chicago Press.

Eichengreen, B. (1991). Is europe an optimum currency area? NBER Working Paper, 3579. doi:10.3386/w3579.

Enderlein, H., \& Haas, J. (2015). What would a European finance minister do? A proposal. Jacques Delors Institute Policy Paper, 145.

European Commission. (2012). Communication from the Commission of 28.11.2012: A blueprint for a deep and genuine economic and monetary union, launching a European Debate (COM(2012) 777 final).

European Commission. (2016). Report on Public Finances in EMU. European Economy Institutional Papers, 045.

Eurostat. (2017). Eurostat database. Retrieved 15.04.2017 from http:/ / ec.europa. eu/eurostat. 
Farhi, E., \& Werning, I. (2017). Fiscal unions. American Economic Review, 107(12). doi:10.1257/aer.20130817.

Furceri, D., \& Zdzienicka, A. (2013). The euro area crisis: Need for a supranational fiscal risk sharing mechanism? IMF Working Paper, 13/198.

Geeroms, H., Ide, S., \& Naert, F. (2014). The European Union and the Euro. Cambridge: Insertia.

Geeroms, H., Moesen, W., \& De Corte, S. (2011). The European Union at a crossroads: an action plan. European View, 10. doi:10.1007/s12290-011-0180-4.

Gros, D. (2014). A fiscal shock absorber for the eurozone? Insurance with deductible. Intereconomics, 49(4).

Gros, D., \& Belke, A. (2015). Banking union as a shock absorber: lessons for the eurozone from the US. Brussels: CEPS.

Gros, D., \& Mayer, T. (2010). Towards a Euro(pean) Monetary Fund. CEPS Policy Brief, 202.

Huart, F. (2013). Is fiscal policy procyclical in the euro area? German Economic Review, 14(1). doi:10.1111/geer.12000.

Iara, A. (2016). Revenue for EMU: A contribution to the debate on fiscal union. CESifo Economic Studies, 62(2). doi:10.1093/cesifo/ifw012.

IMF. (2017a). Government finance statistics database. Retrieved 15.04.2017 from https://www.imf.org.

IMF. (2017b). World economic outlook database. Retrieved 10.04.2017 from https://www.imf.org.

Juncker, J.C., Tusk, D., Dijsselbloem, J., Draghi, M., \& Schulz, M. (2015). Completing Europe's economic and monetary union. Five Presidents' Report. Brussels: European Comission.

Kalemli-Ozcan, S., Luttini, E., \& Sorensen, B. (2014). Debt crises and risk sharing: The role of markets versus sovereigns. Scandinavian Journal of Economics, 116(1). doi:10.1111/sjoe.12043.

Kenen, P. (1969). The theory of optimum currency areas: an eclectic view. In R. Mundell, \& A. Swoboda (Eds.), Monetary problems of the international economy. Chicago: University of Chicago Press.

McKinnon, R. (1963). Optimum currency areas. American Economic Review, 53(4).

Mundell, R. (1961). A theory of optimum currency areas. American Economic Review, 51(4).

Mundell, R. (1973). Uncommon arguments for common currencies. In H.G. Johnson, \& A.K. Swoboda (Eds.), The economics of common currencies. London: Allen and Unwin.

Nerlich, C., \& Reuter, W.H. (2015). Fiscal rules, fiscal space and procyclical fiscal policy. ECB Working Paper Series, 1872.

Oates, W.E. (1999). An essay on fiscal federalism. Journal of Economic Literature, 37(3). doi:10.1257/jel.37.3.1120.

Pisani-Ferry, J., Vihriälä, E., \& Wolff, G. (2013). Options for a euro area fiscal capacity. Bruegel Policy Contribution, 01. 
Sorens, J. (2008). Fiscal federalism: a return to theory and measurement. Retrieved 27.03.2017 from http:/ / www.acsu.buffalo.edu.

Thirion, G. (2017). European fiscal union: economic rationale and design challenges. CEPS Working Document, 01.

Tommaso Padoa-Schioppa Group. (2012). Completing the Euro: A roadmap toward fiscal union in Europe. Retrieved 27.03.2017 from http://www.notre-europe. eu.

Van Rompuy, H., Barroso, J.M., Juncker, J.C., \& Draghi, M. (2012). Towards a genuine economic and monetary union. Brussels: European Council.

Véron, N., \& Wolff, G. (2015). Capital markets union: a vision for the long term. Bruegel Policy Contribution, 05.

Von Bogdany, A., Calliess, C., Enderlein, H., Fratzscher, M., Fuest, C., Mayer, F.C., Schwarzer, D., Steinbeis, M.,Stelzenmüller, C., von Weizsäcker, J., \& Wolff, G. (2013). Aufbruch in die Euro-Union. Die Zeit, 17 October.

Wolff, G. (2012). A budget for Europe's monetary union. Bruegel Policy Contribution, 2012(22).

\section{Acknowledgements}

Author contributions: author has given an approval to the final version of the article.

Funding: this research was fully funded by the Maria Curie-Skłodowska University, Faculty of Economics statutory sources.

Note: the results of this study were presented at 9th International Conference on Applied Economics Contemporary issues in Economy (June 22-23, Toruń, Poland). 


\section{Appendix}

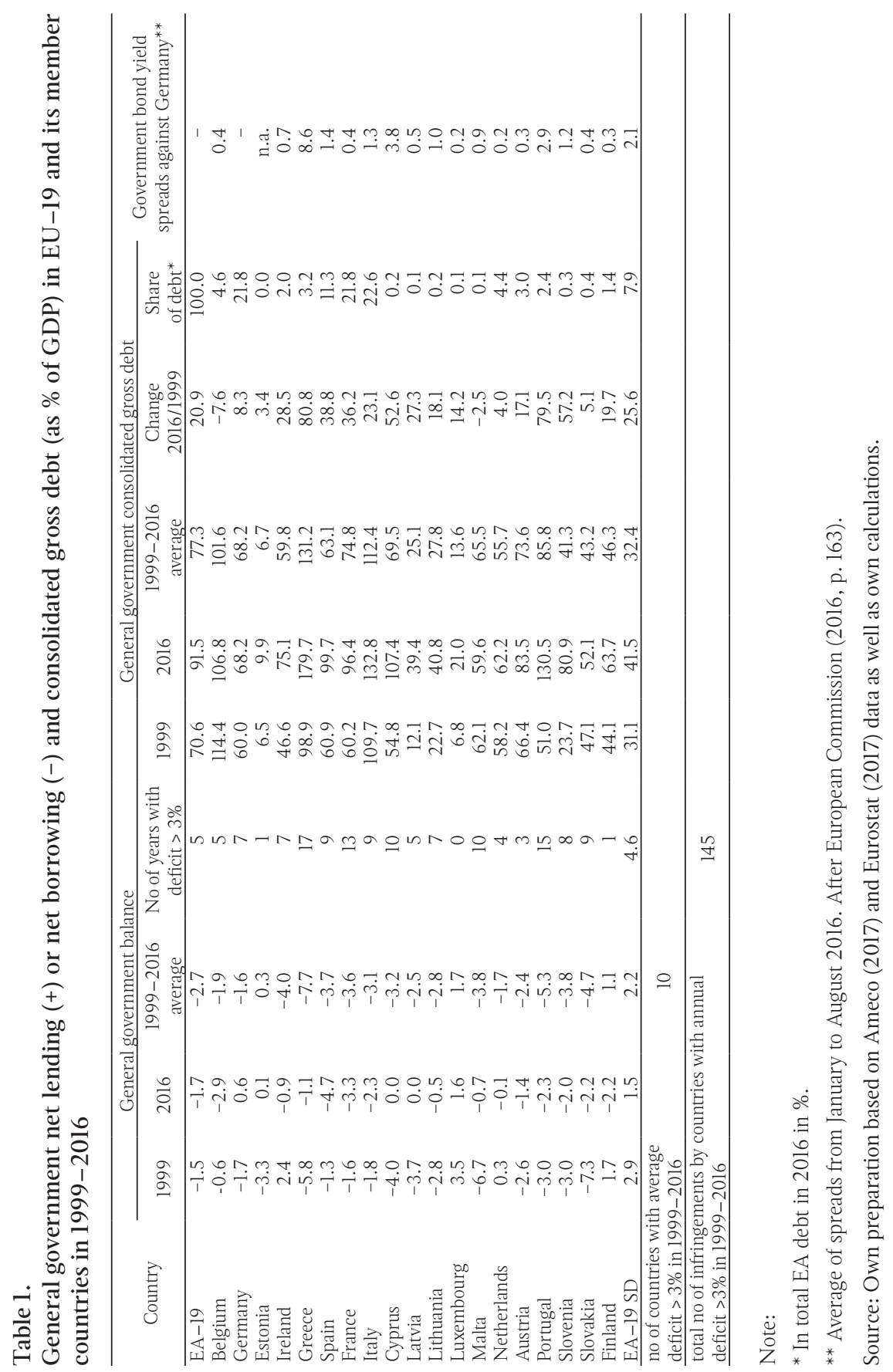




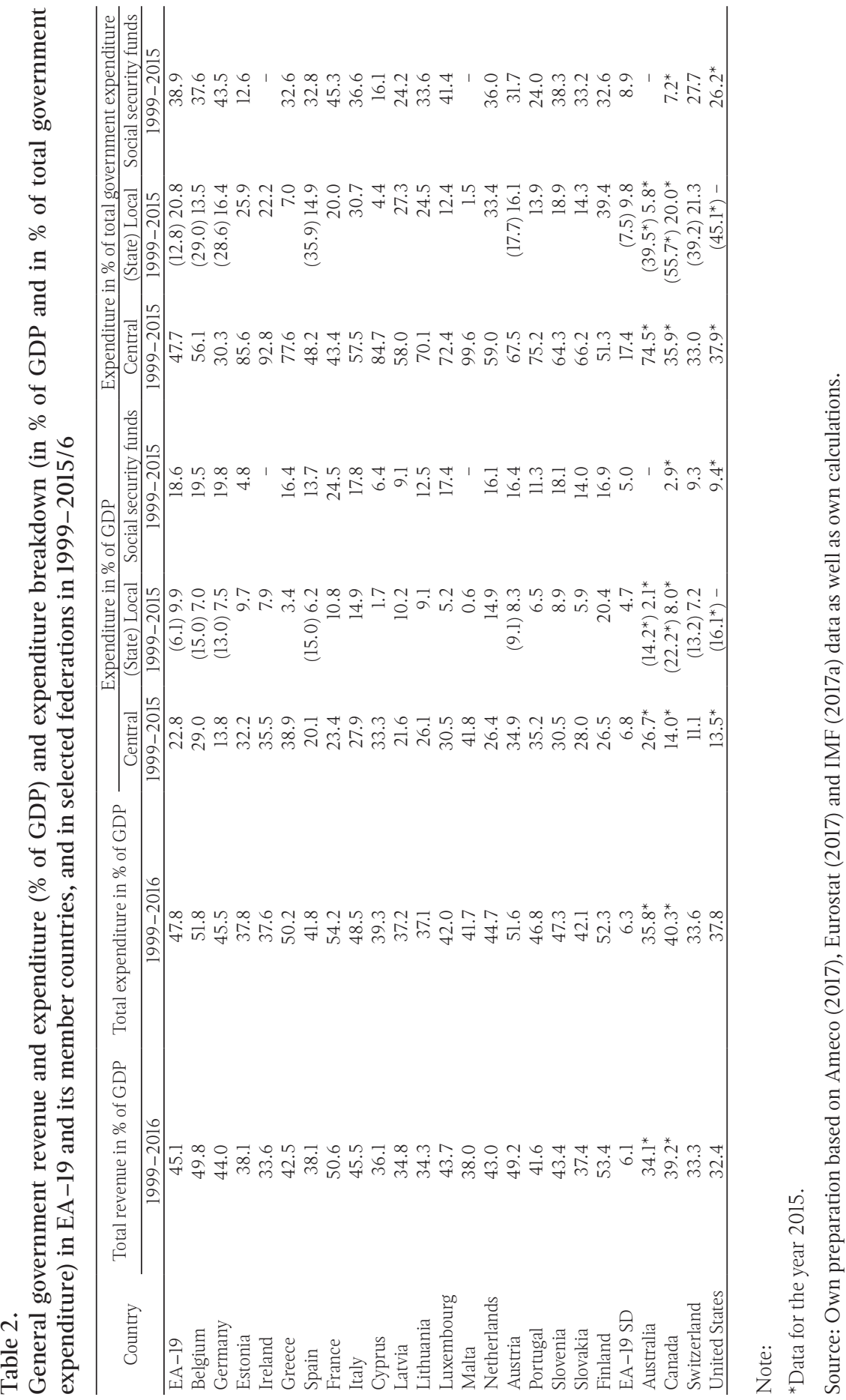




\section{Chart 1.}

Changes y-o-y in the general government structural primary balance (pp of GDP) and in the cyclical component (pp of GDP), and output gap (\% of potential GDP) in EA-19 in 1999-2017

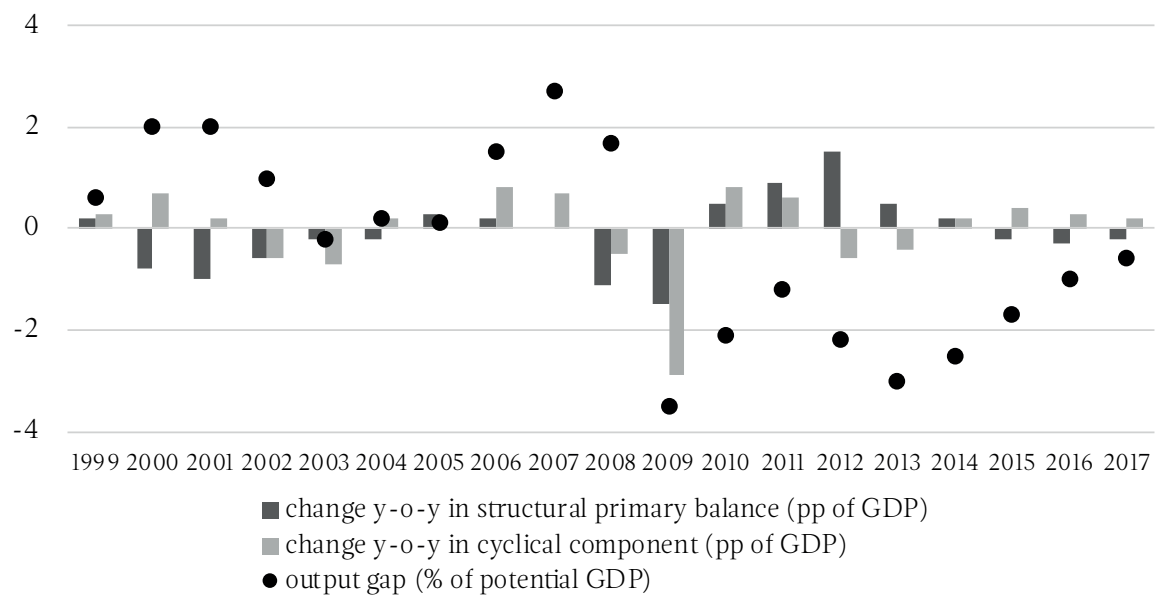

Source: Own preparation based on Ameco (2017) and IMF (2017b) data as well as own estimates. 